\title{
Experimental Study of Index Length for Ngram Full Text Search System
}

\author{
Hiroshi YamamotoＮon-member（Hitachi, Ltd. yamamohi@itg.hitachi.co.jp) \\ Hiroshi Tsuji Member (Osaka Prefecture University tsuji@ie.osakafu-u.ac.jp)
}

Keywords : full text search, Ngram index, document management, information searching systems

Ngram indexing method is the most popular algorithm for the Japanese full text search system where each index consists of serial $\mathrm{N}$ characters. Especially the full text search for Japanese text usually has the 2gram characters index as base in order to save the volumes of the index file, and avoid false drops in the full text search system because indices are uniformly based on 2 grams that are extracted from target documents. On the other hand, the disadvantage is less efficient of searching because of increasing the times for AND operations between 2gram indices. As the solution for this disadvantage, there is the method to create and use higher-gram indices additionally. With this method, higher-gram indices which consist of 3 or more gram can be added, and used for the first search. If there are no higher-gram indices correspond to the search term, 2gram indices can be used for the search.

With creating and using higher-gram indices, the principle for creating of higher-gram indices to save the waste of above-mentioned AND operation should be needed. For creating efficient higher-gram indices, two approaches can be suggested. The first approach, which can be named the Search Term Intensive approach, depends on the frequency of search terms in search applications. And the second one, which can be named the Database Intensive approach, is focused the frequency of terms in document database.

Although the additional higher-gram index is expected to improve the performance for searching indices, we have no experimental evaluation with additional higher-gram indices. This paper presents the evaluation about improving the text search performance with additional higher-gram indices on condition with the above-mentioned approach and the number of $\mathrm{N}$ characters which consists of Ngram indices, and the number of documents for database. And in the evaluation, the length of
Ngram indices can be studied.

On the concrete evaluation, this study support 200 thousand documents for search, and creating 3 or 4 gram indices with Search Term Intensive approach. Concerning the evaluation for $5 \mathrm{gram}$ or higher-gram indices, 5 characters in document database can be convert to 3 sequence of characters which don't appear in document database, and simulated with 3 gram indices due to the characteristic of search engine. Figure 1 shows the sample appearance of histogram with the evaluation of $5 \mathrm{gram}$ or higher-gram indices. I1000 means using thousand 5 gram or higher-gram indices.

Based on above-mentioned experimental evaluation this study analyzes the concrete performance for the search time.

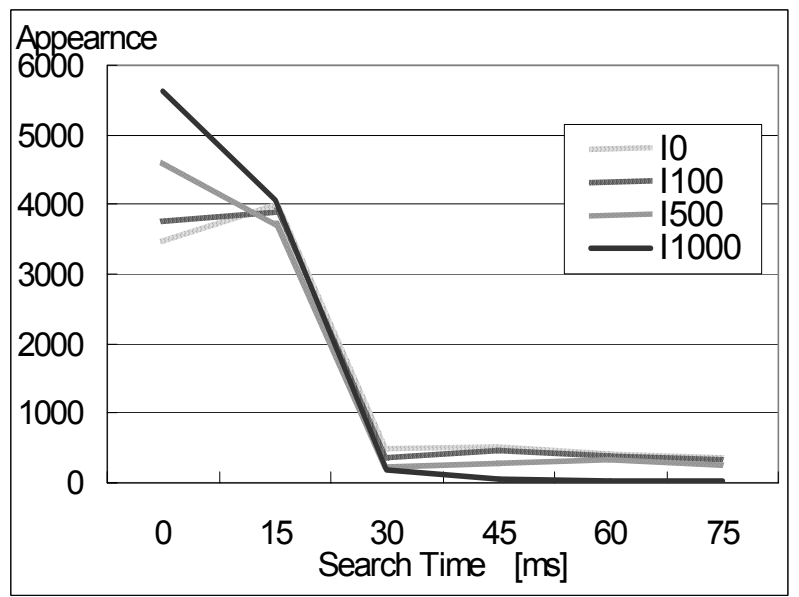

Fig. 1. Histogram of search time with $\mathrm{S} 1000$ 


\title{
Ngram 型全文検索システムにおける \\ インデクス長の実験的検討
}

\author{
非会員 山本 裕* 正員辻 洋** \\ Experimental Study of Higher-gram Index Length \\ for N-gram Full Text Search System \\ Hiroshi Yamamoto*, Non־member, Hiroshi Tsuji**, Member
}

\begin{abstract}
$\mathrm{N}$-gram indexing method is the most popular algorithm for the Japanese full text search system where each index consists of serial $\mathrm{N}$ characters. Especially the full text search for Japanese text usually has the 2-gram characters index as base in order to save the volumes of the index file. Although the additional higher-gram index is expected to improve the performance for searching indices, we have no experimental evaluation with additional higher-gram indices. This paper presents the evaluation about improving the text search performance with additional higher-gram indices by Search Term Intensive Approach which decides the term for higher-gram indices depend upon the appearance ratio in application programs as the searching term. On the concrete evaluation, the number of paper articles for searching is one or two hundred thousands, and the simulation for 5 or more gram additional indices can be applied add to evaluation for 3,4-gram additional indices.
\end{abstract}

キーワード : 全文検索, N-gram インデクス, 文書管理, 情報検索システム

Keywords : full text search, N-gram index, document management, information searching systems

\section{1. 緒言}

全文検索システムの方式には $\mathrm{n}$ 文字から構成される $\mathrm{N}$ gram インデクスを適用した全文検索方式が知られており (1)(2)，特に日本語の全文検索方式としては，2gram インデク ス方式が採用されている(3) (6)。本方式の利点の 1 つは，検 索語が単語として意味をなさない文字列であっても検索漏 れが発生しないことである。これは，文書データベース中 の全文書の文字列を対象としてインデクスを作成するため である。

一方, 欠点はインデクス照合時の AND オペレーション回 数が増大寸ることである。これを改善する手法として，付 加的に高次インデクスを作成する方法がある(9)(10)。本方式 の特徵は 3gram 以上の高次インデクスを追加し, 検索の最 初にこの追加インデクスを参照し, 検索語に対応する高次

\footnotetext{
* 日立製作所 ソフトウェア事業部

干541-0057 大阪市中央区北久宝寺町三丁目 3-8

Software Division, Hitachi, Ltd.

3-3-8 Kitakyuhoji-cho Chuo, Osaka, 541-0057

** 大阪府立大学 大学院工学研究科

干599-8531 堺市学園町 1-1

Osaka Prefecture University.

1-1 Gakuen-cho, Sakai, Osaka 599-8531
}

インデクスが存在しない場合のみ, 従来通り $2 \mathrm{gram}$ インデ クスを参照することにある。

このとき, 2 gram 方式の AND オペレーションを有効に 削減するための追加高次インデクス作成指針が必要であ る。追加高次インデクスの作成に関して, 検索頻出語に着 目するアプローチ(12)(13)やデータベース中の出現頻度が高い 語に着目するアプローチ(14)などの指針が考えられる。

追加高次インデクス方式を使用すれば 2gram 全文検索性 能が改善できると言われているが, 実際に効果があるかど うかは検証する必要がある。そこで本研究では, 上記の各々 の高次インデクス作成アプローチ, 高次インデクス Ngram 数, および検索対象文書件数を条件として評価する。この 評価の中で Ngram のインデクス長の実験的検討も行う。

本研究では, 20 万件の新聞記事を対象とし, 最初に検索 頻出語に着目したアプローチを適用した追加高次インデク ス作成, 3,4gram 追加高次インデクスの評価を行う。次に, 5 gram 以上の追加高次インデクスに関して, 検索語そのも のを高次インデクスとして追加するため文書中の検索語の 文字列置換を行い, 高次インデクスをシミュレートした環 境にて実験を行う。

以下 2 章では, Ngram 型全文検索システムと追加高次イ 


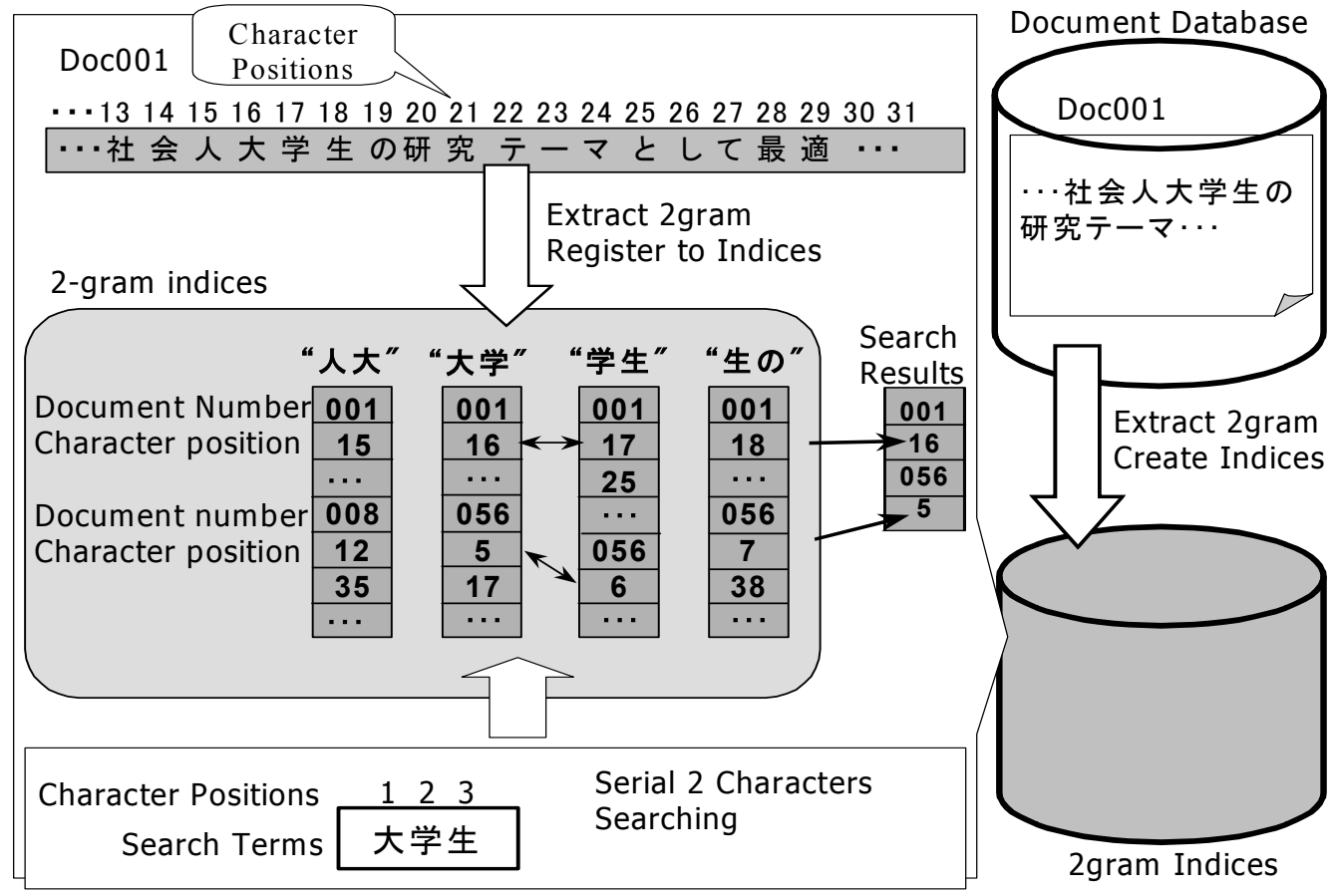

図 1 2gram インデクスを適用した全文検索方式の概要

Fig. 1. Outline of searching with 2gram indexing

ンデクス方式を説明する。 3 章では追加高次インデクス方式 の課題を提起し，4 章および 5 章では検索性能の実証評価を 行いその傾向を分析する。

\section{Ngram 型全文検索と追加高次インデクス方式}

〈2·1〉 2gram 全文検索インデクス方式の概要 日本 語の全文検索方式として，検索語が $\mathrm{n}$ 文字から構成される という特徵から 1 文字を 1 gram と定義し文字列単位にイン デクスを作成する方式がある(2)。特に,多くの日本語の単語

(検索語) の構成が，3 文字以上の文字列と，それだけでは 意味を成さない 2 文字で構成されていること, インデクス

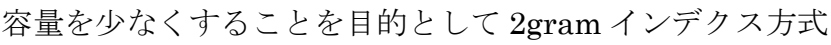
が採用されている(3) (6)。

図 1 に 2gram インデクスでの日本語全文検索方式の概要 を示寸。文書データベース中の全ての文書から 2 文字列の インデクスを作成する。各々のインデクスは，当該文字列 が出現する文書番号と文書中の出現文字位置を情報として 保持する。例えば，”大学” という2 $2 \mathrm{gram}$ は文書番号 001 の 16 文字位置と, 文書番号 056 の 5 及び 17 文字位置に出現 することを示す。検索する場合には，検索語を各 $2 \mathrm{gram} に$ 分割し, 該当インデクスを照合し, 隣接判定により検索を 行う。図 1 で”大学生”を検索する場合, ”大学”と”学生”の各 インデクスの同一文書番号の文字位置の隣接判定により”大 学生”の文書中の出現を認識する。

$\langle 2 \cdot 2\rangle \quad \mathrm{gram}$ 全文検索インデクス方式の課題 2gram 方式の利点は, 検索語が全く意味をなさない語であっ ても，検索漏れが発生しないことである。一方，検索業務 上で頻繁に使うインデクスと全く使われないインデクスと

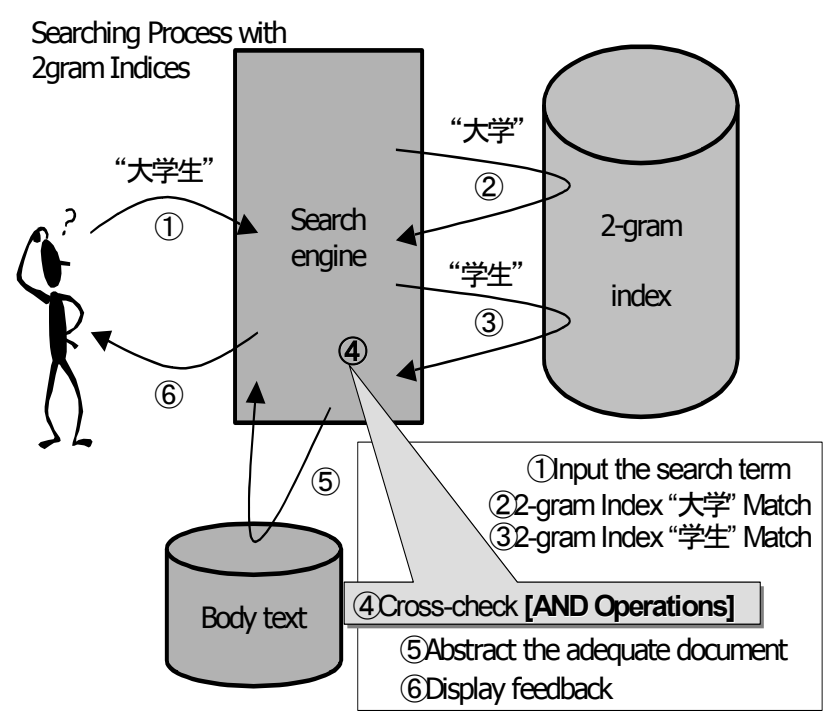

図 2 2gram インデクス方式

Fig. 2. 2gram indexing method

を同様に作成・検索したり，容量の大小に関わらず画一的 にインデクスを作成・検索したりするため, 容量が増大し, インデクス参照効率が悪くなるという欠点がある。

また, 3 文字以上の検索の場合, 図 2 に示すように, $2 \mathrm{gram}$ インデクスの照合(2)(3)後に, 隣接判定であるAND オペレ ーション(4)をを行う方式であるため, 検索語の文字列が長い 場合には性能が悪くなる。

$\langle 2 \cdot 3\rangle$ 追加高次インデクス方式について これら 2 つの課題の解決方法として, 付加的に高次インデクスを作 成し, 検索する方法(追加高次インデクス方式)が提案されて 


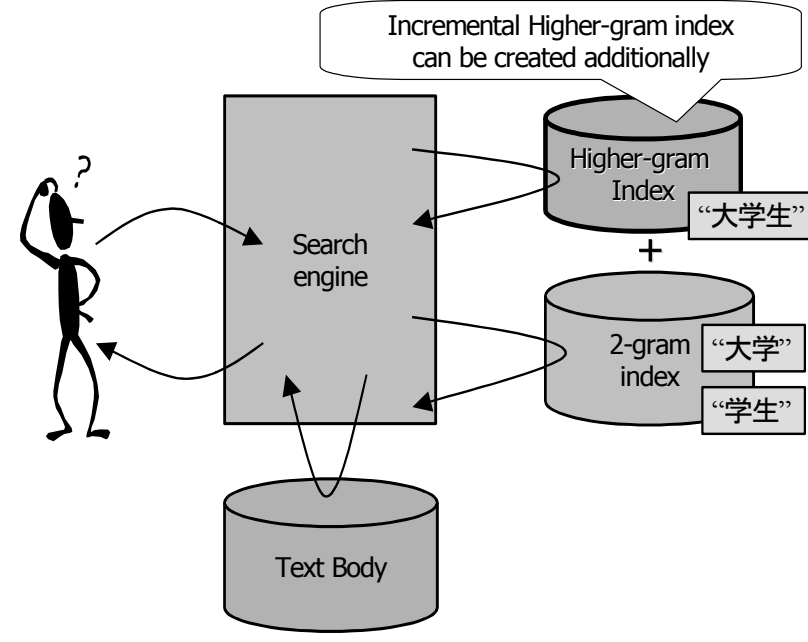

図 3 追加高次インデクス方式

Fig. 3. Incremental Higher-gram Indexing Method

いる(9)(10)。文書中の全ての文字列に関して高次インデクス を作成すると, 容量が増大寸るため, 必要な検索語だけ追 加するという考え方である。

業務中の頻出語を対象として高次インデクスを別の転置 ファイルとして作成し，定義した頻出語の検索に使用する 高速化手法(11)があるが。この手法と比較して，追加高次イ ンデクス方式は，基本の 2 gram に高次インデクスを付加す るため, 追加高次インデクスを使う “「頻出語」 +1 文字” の検索の場合も，従来 $2 \mathrm{gram}$ 使用時の検索精度を損なうこ とがない利点がある。

追加高次インデクス方式の場合，最初に検索語に該当す る高次インデクスを参照するため, 頻出語に関して優先的 に高次インデクスを作成・使用するなどの最適化を図るこ とが可能である。また，図 2 に示す 2 gram インデクス間の AND オペレーションを削減することができる。つまり, 図 3 においては, ”大学生”を検索する場合, ”大学生”の追加高 次インデクスが存在するため, 図 2 での”大学”及び”学生”の 2gram インデクス閒の AND オペレーションは不要になる。

\section{3. 追加高次インデクス方式の課題}

〈3.1〉追加高次インデクス適用時の両刃の問題点 追加高次インデクスを使えば, インデクス照合時の AND オ ペレーションが削減できるが，インデクス容量が増大する とシステム資源(ディスクおよびメモリ)を圧迫し，IO が多 発する。つまり, 無秩序に追加高次インデクスを作成して も, 肝心な頻出語検索時の 2 gram AND オペレーションを 有効に削減できず，検索性能が改善しない可能性がある。 従って, 必要最小限の最適な検索語に関して, 高次追加イ ンデクスを作成する必要がある。

〈3·2〉追加高次インデクス選定指針について 性能 を改善するためには，次の追加高次インデクスを作成する 指針の明確化が必要である。

（a）追加高次インデクス作成対象の検索語の選択方法 （b）追加高次インデクスの作成数

(c) 検索対象文書数, インデクス容量, メモリ容量やデ ィスク容量などのシステム諸元

ここで(a)の追加高次インデクス作成対象語(検索語)の選 択方法に関して考えてみる。

検索業務中によく出現する検索語や，容量の大きいイン デクスに対応する検索語を対象とすると有効な AND オペ レーション削減の効果がありそうである。この観点から, 追加高次インデクスの対象語の選択方法に関して, 以下 2 つのアプローチが考えられる。

1 つ目はデータベース(DB)インテンシブアプローチ，も う 1 つはサーチタームインテンシブアプローチである。こ こで「インテンシブ」とは,「何を基準として追加高次イン デクスを作成するかということ」と定義する。

前者のアプローチは，検索対象文書(文書 DB)中に出現す る頻度に焦点を絞り, 文書 DBのtf（term frequency:検索 語の出現回数)及び df(document frequency: 検索語が出現 する文書数)が多い検索語の上位の一定数を対象として, 高 次インデクスを作成するアプローチである。本アプローチ は，tf 及び df が大きい検索語は，2gramインデクス容量が 大きく, 3gram 以上の追加高次インデクスを作成・検索す ることで，インデクス照合量を削減できることを目的とし ている。但し, 本方式では当該検索語が業務中に出現する 頻度が少ない場合には，改善効果も小さいと考えられる。

一方, 後者のアプローチは, 検索語としての出現頻度に 焦点を絞り, 頻出語の上位の一定数を対象として, 追加高 次インデクスを作成するアプローチである。出現頻度が高 い検索語の検索性能を高める基本的なアプローチと考えら れる。

\section{4. 追加高次インデクス有効性の実証評価計画}

本章では，2gram 方式と比較した追加高次インデクス方 式での性能を，具体的な実験を通して評価して行く。以下 に実証評価の方針を示す。

（1）追加高次インデクス作成対象の検索語選択方法に 関して ; 以下のアプローチで選択し検索性能を実証する。
(a) サーチタームインテンシブアプローチ
(b) データベースインテンシブアプローチ

（2）検索対象文書件数;

10 万件 100 万件程度の文書数を対象とする。

（3）追加高次インデクスの N-gram インデクス長に関 して; 以下の gram 数の高次インデクス検索性能を実証す る。

（a）3,4gram（検索エンジンの特質に依存）

(b) 5gram 以上

今回は, サーチタームインテンシブアプローチでの追加 高次インデクス作成，20 万件の検索対象文書での実証を優 先した。また, 追加する高次インデクス長は 3,4 gram およ び $\operatorname{Ngram}(\mathrm{N} \geqq 5)$ とした。但し， $\mathrm{N} \geqq 5$ の場合のインデクス に関しては, 文書中の 5 文字以上の構成語を 3 文字に置換 
し, 当該 3 文字 $(3 \mathrm{gram})$ の高次インデクスを追加した環境で $5 \mathrm{gram}$ 以上の追加高次インデクスの適用効果を模擬的に検 証した。

\section{5. 追加高次インデクスを適用した実証評価}

〈5·1〉 サーチタームインテンシブによる追加高次イン デクス適用時の評価

(a) 評価方法の概要;

出現頻度が高い検索語に関して, 上位の一定数を対象と し, 追加高次インデクスを作成する。この頻出語が検索業 務中に出現する度合を変化させ, 4 種類の検索パターンを設 定する。また, 出現数上位の検索語を対象とし, 追加高次 インデクス作成数を変えた 4 種類のインデクスパターンを 設定する。

各検索およびインデクスパターンの組合せ条件で平均検 索時間及び度数分布を算出し，検索中の追加高次インデク スの使用率を変えた条件での検索性能の傾向を評価する。

(b) 検索パターンについて;

上位頻出語 $(\mathrm{M}$ 語)の出現度合いに関して, ジフの法則 (Ziph's law)(15)(16)を適用した出現頻度(回数)と出現順位(回 数ランキング)の条件を設定する。ジフの法則によれば，シ ェアは順位に反比例する $((\mathrm{n}$ 位のシェア $)=(1$ 位のシェア $)$ ／n）といわれておりこれに応じて, 検索業務（10,000 検索 語）中の出現頻度第 1 位の出現回数を変数として, 検索中 での頻出語の出現の偏りを変えた検索パターンを設定す る。

(c) インデクスパターンについて；

頻出語ランキング上位 $\mathrm{M}$ 語 $(\mathrm{M}=10 \sim 100)$ を対象として, 作成する追加高次インデクス数を条件とするインデクスパ ターンを設定する。

\section{〈5·2〉 新聞記事 20 万件を対象とした検索性能評価}

新聞記事 20 万件(記事約 1 年分)を検索対象として, 検索 業務(検索のべ 10,000 回)中の頻出語を主体として追加高次 インデクスを適用し, 検索実行時間の度数分布, 平均值及 び分散值を評価した。実験及び評価の内容を以下に示す。

（1）実験環境

DELL Dimension 4600C(CPU 2.66GHz, 主メモリ 1.0 GB, HD 40GB) Windows XP 環境で動作する全文検索シス テム Bibliothca21 を使用した。まず，3または 4gram イン デクスだけを 2 gram に付加した。

(2) 検索パターン

検索語は経済語 1000 語から各検索パターンの検索語群 をジフの法則に従い構築した。各検索パターンは，検索業 務中の出現回数が第 1 位の検索語の出現回数(A1)を变数と し, A1 を変え頻出語の出現頻度の偏りを変えた 4 種類の検 索 4 パターンを設定した。検索パターンの内容を表 1 に示 す。

表 1 の例では, $\mathrm{S} 1$ では, 出現回数第一位の検索語がアプ リケーション中に 1500 回登場し, 検索語として占める割合 は $15 \%$ であことを示す。
表 1 適用した検索パターン

Table 1. Search cases

\begin{tabular}{|c|c|c|}
\hline $\begin{array}{c}\text { Search } \\
\text { Cases }\end{array}$ & A1 $\left.{ }^{*} 1\right)$ [times] & $\begin{array}{c}\text { Ratio for Appearance in } \\
\text { whole of Application [\%] }\end{array}$ \\
\hline S 1 & 1500 & 15 \\
\hline S 2 & 2000 & 20 \\
\hline S 3 & 2300 & 23 \\
\hline S 4 & 4800 & 48 \\
\hline
\end{tabular}

(*1) Appearance for the Most Appearing Word

表 2 適用したインデクスパターン

Table 2. Index cases

\begin{tabular}{|c|c|c|c|c|c|}
\hline \multirow{2}{*}{$\begin{array}{c}\text { Indexing } \\
\text { Cases }\end{array}$} & $\begin{array}{c}\text { The Number of } \\
\text { Additional Indices }\end{array}$ & \multicolumn{5}{|c|}{$\begin{array}{c}\text { Ratio for Using Additional } \\
\text { Indices [\%] }\end{array}$} \\
\cline { 3 - 6 } & & $\mathrm{S} 1$ & $\mathrm{~S} 2$ & $\mathrm{~S} 3$ & $\mathrm{~S} 4$ \\
\hline $\mathrm{I} 0$ & 0 & 0 & 0 & 0 & 0 \\
\hline $\mathrm{I} 10$ & 10 & 44 & 59 & 67 & 100 \\
\hline I50 & 50 & 68 & 90 & 100 & - \\
\hline I100 & 100 & 78 & 100 & - & - \\
\hline
\end{tabular}

（3）インデクスパターン

新聞記事 20 万件からインデクスを作成する。基本 $2 \mathrm{gram}$ 及び 3,4gram の高次インデクスを追加した数により 4 種類 のインデクスパターンを設定する。追加高次インデクスの 数は, 各々頻出語のランキング上位 $10,50,100$ 語を対象と した。表 2 に各インデクスパターンの内容を示す。

表 2 において，例えば I10 を使った検索では，S1 の検索 パターンは, 検索語の $44 \%$ が 10 個の追加高次インデクスを 使った検索になることを示している。

(4) 検索結果の評価

表 1 及び表 2 の検索パターンとインデクスパターンの組 合せ条件で, 平均検索時間, 分散值と度数分布を評価した。 評価対象は, 検索アプリケーション(10000 回検索)2 回の実 行結果とした。各パターンの平均検索時間を表 3 に, 各パ ターンのインデクス容量と検索時間改善率および swap 発 生回数との関係を表 4 に示す。表 3 および表 4 に示す実験 結果では, 検索パターン S4では, 全ての検索語で高次イン デクスを利用した場合に平均検索時間(17.7\%改善)および分 散に関して改善傾向が認められたが，S1〜S3 に関しては追 加高次インデクスの利用率が高い条件になると, 平均検索 時間・分散值共に劣化傾向にある。これは, 追加高次イン デクスを使用した検索の場合, Windows 環境でのメモリ swap 事象による検索時間の間延びが多発することが原因 である。表 4 に示すように追加インデクス容量が大きくな るほじ, swap 事象が多発し, 追加高次インデクスの性能改 善が認められない結果となった。

メモリ swap 事象を除外した場合の検索時間平均值と分 散に関しては，各検索パターンで改善傾向を確認したが, その改善率は 0.1〜 5\%程度の範囲であり，その効果は低い。

〈5·3〉 Ngram インデクスの評価新聞記事 10 万件 (記事約半年分)を対象として, 検索業務中の頻出語に対して 
表 3 検索パターン及びインデクスパターンごとの検索時間平均值と分散值

Table 3. Average and distribution for search time

\begin{tabular}{|c|c|c|c|c|c|c|c|c|c|}
\hline \multirow{2}{*}{\multicolumn{2}{|c|}{ I-Cases }} & \multicolumn{4}{|c|}{ Including Memory Swap Situations } & \multicolumn{4}{|c|}{ No Including Memory Swap Situations } \\
\hline & & \multicolumn{4}{|c|}{ Search Time $[\mathrm{s}]$} & \multicolumn{4}{|c|}{ Search Time $[\mathrm{s}]$} \\
\hline \multicolumn{2}{|c|}{ S-Cases } & I0(2gram) & $\mathrm{I} 10$ & $\mathrm{I} 50$ & $\mathrm{I} 100$ & I0(2gram) & $\mathrm{I} 10$ & $\mathrm{I} 50$ & $\mathrm{I} 100$ \\
\hline \multirow{4}{*}{$\begin{array}{l}\text { Ave. } \\
{[\mathrm{s}]}\end{array}$} & $\mathrm{S} 1$ & 0.04565 & 0.05195 & 0.05507 & 0.06255 & 0.01602 & 0.01587 & 0.01582 & 0.01580 \\
\hline & $\mathrm{S} 2$ & 0.04759 & 0.06294 & 0.06248 & 0.06868 & 0.01628 & 0.01572 & 0.01566 & 0.01566 \\
\hline & S3 & 0.04250 & 0.06094 & 0.06979 & - & 0.01591 & 0.01586 & 0.01566 & - \\
\hline & $\mathrm{S} 4$ & 0.08896 & 0.07318 & - & - & 0.01568 & 0.01566 & - & - \\
\hline \multirow[t]{4}{*}{ Dis. } & $\mathrm{S} 1$ & 0.25879 & 0.37626 & 0.40706 & 0.54190 & $7.178 \mathrm{E}-06$ & $4.921 \mathrm{E}-06$ & $3.978 \mathrm{E}-06$ & $3.6178 \mathrm{E}-06$ \\
\hline & $\mathrm{S} 2$ & 0.28525 & 0.54100 & 0.47960 & 0.63732 & $1.486 \mathrm{E}-05$ & $1.971 \mathrm{E}-06$ & $1.184 \mathrm{E}-06$ & $1.667 \mathrm{E}-06$ \\
\hline & $\mathrm{S} 3$ & 0.21576 & 0.52194 & 0.67666 & - & $4.861 \mathrm{E}-06$ & $5.680 \mathrm{E}-06$ & $1.626 \mathrm{E}-06$ & - \\
\hline & $\mathrm{S} 4$ & 0.96714 & 0.58497 & - & - & $1.813 \mathrm{E}-06$ & $1.537 \mathrm{E}-06$ & - & - \\
\hline
\end{tabular}

Note: I-Cases: Indexing Cases / S-Cases: Search Cases

Ave.: Average for Searching Time / Dis.: Distribution for Searching Time

表 4 2gram インデクスを適用した全文検索方式の概要

Table 4. Relationship between improving ratio, indices capacity and swap phenomena

\begin{tabular}{|c|c|c|c|c|c|c|c|c|c|c|c|c|c|}
\hline & \multirow[b]{2}{*}{ I-Cases } & \multicolumn{3}{|c|}{$\mathrm{S} 1$} & \multicolumn{3}{|c|}{$\mathrm{S} 2$} & \multicolumn{3}{|c|}{ S3 } & \multicolumn{3}{|c|}{$\mathrm{S} 4$} \\
\hline & & $\begin{array}{l}\text { Capa } \\
.(* 2)\end{array}$ & $\begin{array}{l}\text { Imp. } \\
(* 3)\end{array}$ & $\begin{array}{l}\text { Swap } \\
(* 4)\end{array}$ & $\begin{array}{l}\text { Capa } \\
.(* 2)\end{array}$ & $\begin{array}{l}\text { Imp. } \\
(* 3)\end{array}$ & $\begin{array}{l}\text { Swap } \\
(* 4)\end{array}$ & $\begin{array}{l}\text { Capa } \\
.(* 2)\end{array}$ & $\begin{array}{l}\text { Imp. } \\
(* 3)\end{array}$ & $\begin{array}{l}\text { Swap } \\
(* 4)\end{array}$ & $\begin{array}{l}\text { Capa } \\
.(* 2)\end{array}$ & $\begin{array}{l}\text { Imp. } \\
(* 3)\end{array}$ & $\begin{array}{l}\text { Swap } \\
(* 4)\end{array}$ \\
\hline \multirow{4}{*}{$\begin{array}{c}\text { Swap } \\
(* 1)\end{array}$} & I0 & 1379 & 0 & 98 & 1379 & 0 & 106 & 1379 & 0 & 92 & 1379 & 0 & 138 \\
\hline & $\mathrm{I} 10$ & 1382 & -13.8 & 98 & 1382 & -32.3 & 110 & 1382 & -43.4 & 116 & 1382 & 17.7 & 141 \\
\hline & I50 & 1405 & -20.6 & 106 & 1405 & -31.3 & 117 & 1405 & -64.2 & 117 & 1405 & - & - \\
\hline & I100 & 1434 & -37.0 & 114 & 1434 & -44.3 & 121 & 1434 & - & - & 1434 & - & - \\
\hline \multirow{4}{*}{$\begin{array}{c}\text { Non } \\
\text { Swap } \\
(* 1)\end{array}$} & I0 & 1379 & 0 & - & 1379 & 0 & - & 1379 & 0 & - & 1379 & 0 & - \\
\hline & $\mathrm{I} 10$ & 1382 & 0.94 & - & 1382 & 3.4 & - & 1382 & 0.3 & - & 1382 & 0.1 & - \\
\hline & $\mathrm{I} 50$ & 1405 & 1.2 & - & 1405 & 3.8 & - & 1405 & 1.6 & - & 1405 & - & - \\
\hline & $\mathrm{I} 100$ & 1434 & 1.4 & - & 1434 & 3.8 & - & 1434 & - & - & 1434 & - & - \\
\hline
\end{tabular}

Note: (*1)Swap: Including Memory Swap Situations/ Non Swap: No Including Memory Swap Situations (*2)Capa. [MB]: Total Capacity of Indices （*3)Imp.: Ratio of Improvement for Search time for I0 Pattern $\left({ }^{*} 4\right)$ Swap [times]: Numbers of times for swap phenomena per 2times Execution of the Batch Application

追加高次インデクスを適用し, Ngram 追加高次インデクス $(\mathrm{N} \geqq 5)$ の評価を実施した。前節の実験と同様に，検索実行 時間の度数分布, 平均值及び分散值の傾向を評価する。

\section{（1）実験環境と概要}

本評価では，文書中の 5 文字以上の検索文字列を文書デ ータベース中に存在しない $3 \mathrm{gram}$ に置換し,この $3 \mathrm{gram}$ 高 次インデクスを追加・使用することにより， $\mathrm{N} \geqq 5$ の追加高 次インデクスの効果をシミュレーション評価した。

(2) 検索パターン

経済語 1000 語の出現頻度上位 $\mathrm{M}$ 語 $(\mathrm{M}=100,500,1000) の$ 出現比率が異なる 4 種類の検索パターンを設定した (S100/S500/S1000/Smix)。各検索パターン Sx の $\mathrm{x}$ の值は 評価アプリ中に出現する検索語の数を示す。表 5 に各検索 パターン(Search Cases)の検索語の出現比率を示す。

各検索パターンの評価アプリは 10000 語の検索コマンド で構成される。また，M は出現頻度ランキングを示す。

表 5 において, S500 の検索パターンは評価アプリ中の 10000 件の検索のうち，20\%がベスト $100,80 \%$ がベスト 101 500 の検索語で構成, Smix は 10000 件の検索のうち $61 \%$ が頻出語ベスト 100 の検索語, $24 \%$ 頻出語ベスト 101
表 5 適用した検索パターン

Table 5. Search cases

\begin{tabular}{|c|c|c|c|c|}
\hline $\begin{array}{c}\text { Search } \\
\text { Cases }\end{array}$ & $\mathrm{M}=1-100$ & $\mathrm{M}=101-500$ & $\mathrm{M}=501-1000$ & $\begin{array}{c}5 \text { 文字 } \\
\text { 以上検 } \\
\text { 索語 }\end{array}$ \\
\hline S100 & 100 & 0 & 0 & 75 \\
\hline S500 & 20 & 80 & 0 & 70 \\
\hline S1000 & 10 & 40 & 50 & 60 \\
\hline Smix & 61 & 24 & 15 & 70 \\
\hline
\end{tabular}

〜 500 の検索語, $15 \%$ が頻出語ベスト 501〜1000 の検索語 で構成されることを示す。なお, 評価アプリ中の検索語に 関して, 5 文字以上の検索語は, 対象文書中に他に存在しな い3 文字に変換して評価した。5 文字以上の検索語の評価ア プリ中の出現比率は 60 ～75\%の比率である。

(3) インデクスパターン

新聞記事 10 万件から全文検索インデクスを作成する。な お，検索対象文書中の検索語に該当する 5 文字以上の語を， 検索対象文書中に他に存在しない固有の 3 文字に置換した。 文字列置換後の検索対象文書群から 2 gram および 3 gram 追加高次インデクスを作成した。前節の実験と同様に, 
表 6 適用した検索パターン

Table 6. Index cases

\begin{tabular}{|c|c|c|}
\hline Index Cases & $\begin{array}{c}\text { The Number of } \\
\text { Additional Indices }\end{array}$ & Indices Size [MB] \\
\hline I0 & 0 & 674 (2gram のみ) \\
\hline I100 & 100 & $674+1$ \\
\hline I500 & 500 & $674+4$ \\
\hline I1000 & 1000 & $674+7$ \\
\hline
\end{tabular}

表 7 Ngram 追加インデクス使用時の平均検索時間 $(\mathrm{ms})$ Table 7. Search time with N-gram indices (ms)

\begin{tabular}{|c|c|c|c|c|}
\hline \multirow{2}{*}{$\begin{array}{c}\text { Search } \\
\text { Cases }\end{array}$} & \multicolumn{4}{|c|}{ Index Cases } \\
\cline { 2 - 5 } & I0 & I100 & I500 & I1000 \\
\hline S100 & 14.07 & 6.62 & 6.15 & 6.31 \\
\hline S500 & 21.27 & 21.26 & 6.30 & 7.26 \\
\hline S1000 & 25.31 & 25.58 & 18.93 & 7.91 \\
\hline Smix & 19.61 & 19.52 & 14.47 & 7.58 \\
\hline
\end{tabular}

3gram の追加高次インデクス数により 4 種類のインデクス パターンを設定(I0/I100/I500/I1000)した。

表 6 に各インデクスパターンの追加高次インデクスの作 成数とインデクス容量を示す。例えばI0 は全てが $2 \mathrm{gram}$ イ ンデクスのパターン, I500 は追加高次インデクスを, 前述 の出現頻度上位 $\mathrm{M}$ 語 $(\mathrm{M}=500)$ 分作成した結果，インデクス 容量は基本 2 gram $(674[\mathrm{MB}])+$ 追加高次インデクス $(4[\mathrm{MB}])$ の合計 $678[\mathrm{MB}]$ であることを示す。

(4) 検索結果の評価

表 7 に表 5 および表 6 の検索パターンとインデクスパタ ーンの組み合わせ条件ごとの平均検索時間を示す。

平均検索時間に関して, 前節 20 万件対象の $3,4 \mathrm{gram} の$ 実 験結果に比べて改善が見られた。I500 およびI1000 のイン デクスパターンの場合, 全検索パターンにおいて改善効果 が確認できた(I500 で 25〜 70\%，I1000 で 55〜70\%)。

また，図 4 に例として 1000 の平均検索時間の度数分布 を示す。S1000 の場合，0１5ms のレンジを見ると追加高 次インデクスの比率が高いほど度数が大きい。また $30 \mathrm{~ms}$ 以上のレンジになると, 追加高次インデクスの比率が低い ほど度数が大きい。この傾向は，検索パターン全てに見ら れ，追加高次インデクスを使った改善傾向が全般に渡って 見られる結果となった。

この結果は, 追加高次インデクス対象の検索語を 3gram 文字列に置換したこと，置換した文字列が一般の文書には 出現しない文字列であったことから余分な追加高次インデ クス作成が抑制された結果，インデクス容量が抑制され， swap 発生状況が極小化したことが要因と考える。

また, swap 事象を除いた条件でも, 前節 3,4gram の追加 高次インデクス使用時の結果と比較して，平均検索時間の 改善率が向上していることから $\mathrm{N}-\operatorname{gram}(\mathrm{N} \geqq 5)$ の追加高次 インデクスの効果が認められる結果となった。

〈5・4〉 20 万件での Ngram インデクスの評価＼cjkstart前記 新聞記事 10 万件での評価では Ngram 高次インデクスの効

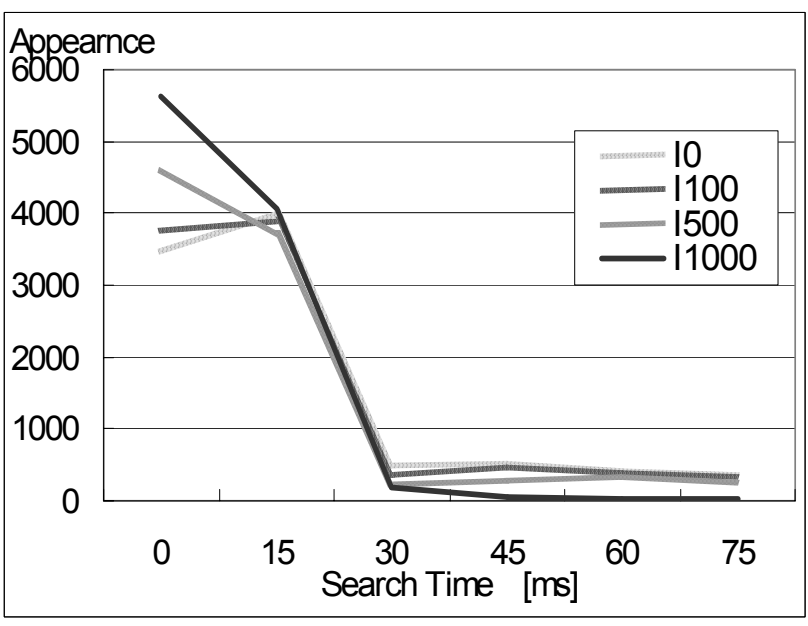

図 $4 \mathrm{~S} 1000$ の検索時間の度数分布

Fig. 4. Histogram of search time with S1000

表 $8 \operatorname{Ngram}(\mathrm{N} \geqq 5)$ インデクスの評価

Table 8. Evaluations for $\operatorname{Ngram}(\mathrm{N} \geqq 5)$ indices

\begin{tabular}{|c|c|c|c|}
\hline & & $\begin{array}{l}\text { 2gram 份 } \\
\text { クス(I0)使用 }\end{array}$ & $\begin{array}{l}\text { 高次インデクス } \\
\text { (I50)使用 }\end{array}$ \\
\hline \multirow{3}{*}{$\begin{array}{l}\text { Ngram } \\
(\mathrm{N} \geqq 5) \\
\text { 評価 }\end{array}$} & $\begin{array}{l}\text { 検索時間 } \\
\text { (swap 込)[S] }\end{array}$ & 0.10312 & $\begin{array}{c}0.09908 \\
\text { (4\%改善) }\end{array}$ \\
\hline & $\begin{array}{l}\text { 検索時間 } \\
\text { (swap 除)[S] }\end{array}$ & 0.01633 & $\begin{array}{c}0.01597 \\
\text { (2\%改善) }\end{array}$ \\
\hline & $\begin{array}{l}\text { イソデクス容量 } \\
\text { [MB] }\end{array}$ & 1462 & $\begin{array}{l}1482 \\
(+20) \\
\end{array}$ \\
\hline \multirow{3}{*}{$\begin{array}{l}3,4 \text { gram } \\
\text { 評価 } \\
\text { (参考值) }\end{array}$} & $\begin{array}{l}\text { 検索時間 } \\
\text { (swap 込) [S] }\end{array}$ & 0.04759 & $\begin{array}{c}0.06248 \\
\text { (-31\%改善) }\end{array}$ \\
\hline & $\begin{array}{l}\text { 検索時間 } \\
\text { (swap 除)[S] }\end{array}$ & 0.01628 & $\begin{array}{c}0.01566 \\
(3.8 \% \text { 改善) }\end{array}$ \\
\hline & $\begin{array}{l}\text { 价デクス容量 } \\
\text { [MB] }\end{array}$ & 1379 & $\begin{array}{l}1405 \\
(+26)\end{array}$ \\
\hline
\end{tabular}

果が認められた。本項では検索パターンを特定し対象文書 が新聞記事 20 万件の環境で Ngram 高次インデクス $(\mathrm{N} \geqq 5)$ の評価を行う。また $3,4 \mathrm{gram}$ 高次インデクスの場合の効果 との比較評価を行う。

検索パターンは新聞記事 20 万件の場合のジフの法則に即 した検索パターン S2(表 1)，インデクスパターンは I50(表 2)を適用した。

表 8 に Ngram インデクスを使用した場合の平均検索時間 と $2 \mathrm{gram}$ と比較した改善率, インデクス容量を纏める。ま た 3,4gram を使用した場合の結果と比較する。なお， $3,4 \mathrm{gram}$ の評価環境とは全く同じではないため改善率で評 価する。

検索時間に関して $\operatorname{Ngram}(\mathrm{N} \geqq 5)$ の場合, 高次インデクス 使用で $4 \%$ 程度の改善効果がみられた。これは Ngram の場 合，頻出語をそのまま高次インデクスとして追加したため, 追加高次インデクス容量を抑制できたことにより, 3,4gram の場合に比べて swap 事象の発生頻度が小さくなった(swap に要する時間が小さくなった)ことが要因であると考えられ 


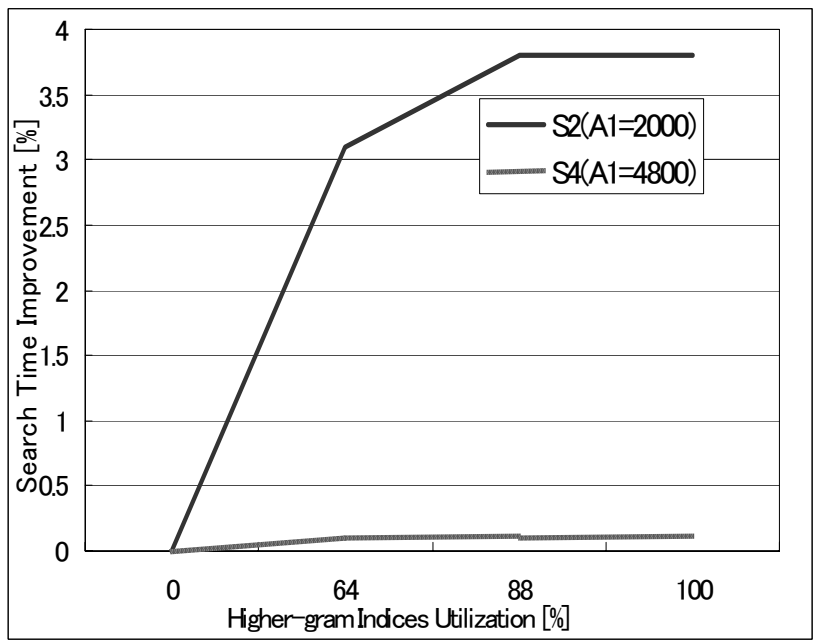

図 5 高次インデクス使用率および改善率

Fig. 5. Relationship between utilizations of higher-gram indices and improvement of search time

る。

〈5.5〉検証結果の分析と評価のまとめ 今回の実験 条件においては, 部分文字列の gram 数を大きくした追加高 次インデクス (3,4gram)の方式では, インデクス容量増大で の swap 現象多発による性能劣化の度合いが，AND Operation の削減·無䭾インデクス照合の削減による効果よ りも大きくなり, 追加高次インデクスの改善効果が認めら れなかった。メモリ swap 事象を除いた評価ではある程度の 改善が認められたことから, 方式自体が無効ではないと考 えられるが，今回の検索環境レベルでは，2gram インデク スの使用が適していると判断できる。

一方,インデクス容量を抑制し swap 事象を抑止した検索 環境で, $\mathrm{N}-\operatorname{gram}(\mathrm{N} \geqq 5)$ 構成の単語そのものに関して, 追加 高次インデクスを使用した場合, 新聞記事 10 万件および 20 万件の環境における検索において，効果があることを検証 できた。本方式では，業務中の 5 文字以上で構成される頻 出語をそのまま高次インデクスとして追加したことで，イ ンデクス容量を抑制することができ, 検索時の swap 事象が 抑制できたためと考えられる。

次に，追加高次インデクスを使った場合の改善率(20 万 件，3,4gram 使用， swap 事象を除いた場合) と各検索パ夕 ーンとの関係を考察する。図 5 に $\mathrm{S} 2$ および $\mathrm{S} 4$ の追加高次 インデクスの利用率と平均検索時間の改善率との関係を示 す。

図 5 において, ジフの法則での出現頻度が第一位の検索 語の出現回数が低い検索パターンの追加高次インデクスに よる改善率が概祊高い傾向（S2>S4）が認められたが，こ れは, 検索タームが偏った検索パターン(S4)において, 効果 がない追加高次インデクスを多く適用した結果と考えられ る。

追加高次インデクスを適用した場合の改善率は, 追加高 次インデクス適用対象の検索語に依存する。表 9 に検索語
表 9 検索語と追加高次インデクス適用時の改善率

Table 9. Improvement of search time for search terms

\begin{tabular}{|c|c|c|c|c|}
\hline \multirow{2}{*}{$\begin{array}{c}\text { Search } \\
\text { Terms }\end{array}$} & \multicolumn{2}{|c|}{ Frequency } & \multirow{2}{*}{$\begin{array}{l}\text { Frequency } \\
\text { in } \mathrm{AP}\left({ }^{*} 1\right)\end{array}$} & $\begin{array}{l}\text { Improvement } \\
{[\%]\left[{ }^{*} 2\right)}\end{array}$ \\
\hline 基䃈年金 & 84 & 157 & 4759 & 0.3 \\
\hline 金融庁 & 1797 & 4201 & 2390 & 0.2 \\
\hline 公定歩合 & 326 & 603 & 284 & 4.8 \\
\hline 失業率 & 1290 & 5082 & 26 & 10.5 \\
\hline $\begin{array}{c}\text { 新株引受権 } \\
\text { 付社債 }\end{array}$ & 134 & 146 & 125 & 13.1 \\
\hline 持ち株会社 & 1005 & 1907 & 77 & 9.6 \\
\hline 子会社公開 & 2 & 2 & 69 & 8.9 \\
\hline
\end{tabular}

と追加高次インデクス適用時の改善率, 検索対象文書中の 出現頻度( $\mathrm{df} / \mathrm{tf})$, 検索アプリ中の出現頻度を示す。

表 9 において,「基礎年金」「金融庁」は $\mathrm{S} 4$ の，「公定歩 合」「失業率」は S2 に出現する検索語である。S2 の検索語 は S4 の検索語に比べて, 概祆追加高次インデクス適用時の 改善率が大きいものが多い結果となった。追加高次インデ クスの効果は概敉検索語の特質に依存し，均一ではないた め, 追加高次インデクスの利用率が同じであっても, 追加 高次インデクスを適用した検索の改善効果が高いほど検索 パフォーマンスが高まると考えられる。従って, 改善率が 高く, アプリ中の出現頻度の高い検索語の追加高次インデ クスを作成することが必要になると考えられる。

また, 表 9 の「新株引受権付社債」「持ち株会社」「子会 社公開」は, $\operatorname{Ngram}(\mathrm{N} \geqq 5)$ 追加インデクス使用時に該当す る。基本的に 3,4gram の場合に比べて改善率が高く, df お よび tf が大きい検索語は, 改善率が大きい傾向が見られる。

\section{6. 結言}

今回 10-20 万件の検索文書を対象にして，3,4gram の追 加高次インデクスを適用した実証評価を行ったが，インデ クス容量の増大に起因するメモリ swap 事象の頻発により 性能改善は認められず，この条件では 2gram 方式の適用が 妥当であるという結果となった。

その一方, N-gram 追加高次インデクスでのシミュレート 実験では効果が認められたため, 頻出語が絞られる検索環 境において, インデクス容量を抑えながら, 特定の頻出語 を対象として追加高次インデクスを利用することは有効で あった。

これらの実験的な検討は普遍的なものではないが，一つ の知見になっており，また，別の条件下での評価手順・評 価方法を策定するときに参考になるものと考えている。

今後の課題としては, 検索文書件数がさらに多い環境や, 追加高次インデクス利用時の改善率が高まる可能性がある 環境での性能評価, 性能改善率が高くなる検索語を対象と した追加高次インデクスの適用による性能改善効果の検証 を行い，少しでも一般的な指針を確立していきたい。

(平成 17 年 1 月 28 日受付，平成 18 年 3 月 20 日再受付) 


\section{文献}

(1) M. Damashek : "Gauging Similarity with N-Grams: LanguageIndependent Categorization of Text." Science, Vol.267, pp.843848, 10 February (1995)

(2) K. Hosono : "Current State of Research and Development on Digital Libraries in Japan", 62nd IFLA General Conference Conference Proceedings, pp.25-31, August (1996)

(3) K. Matsui, I. Namba, and N. Igata : "Hi-speed Full text Search Engine", IPSJ SIG Notes Contents Digital Document No.007 (1997)

(4) Hatakeyama et al. :「ソフトウェアによるテキストサーチマシンの 実現」，IPSJ, 情報学基礎研究報告, Vol.92, No.32，25-2，pp.19-25 (1992)

（5） Kikuchi et al.：「日本語文書高速全文検索の一手法」，IPSJ，情報学 基䃈研究報告, Vol.92, No.32, 25-2, pp.9-16 (1992)

(6) Y. Kawashimo, et al. : "Development of full text search system Bibliotheca/TS", (in Japanese). In Proc. of 45th JIPS Conf. (3), pp.241-242 (1992)

(7) M. Yokoyama : "High-Speed Full-Text Search Engine", FUJITSU. 48, pp.155-158 (1997)

(8) M. Harada, et al. : "An N-gram indexing method for Unicode based search engine", IPSJ SIGNotes Contents Natural Language No.136-017 (1999)

(9) N. Sugaya, et al. : "A full-text search system for large Japanese text basis using n-gram indexing method", proc. 53rd Annual Convention IPS Japan, 5T-2, 3 (1996)

(10) Y. Kawashimo, et al. : "Full Text Search System for Large Structured Document Database, Bibliotheca2 TextSearch(1)" (in japanese) In Proc. of 55th IPSJ Conf. 3-p.107 4N-3

（11） Akamine, et al. : 「高速全文検索のためのフレキシブル文字列イン バージョン法」, Advanced Database Symposium 96, pp.35-42, (1996)

(12) Y. Yamamoto, S. Ohmi, and H. Tsuji : "Incremental Indexing and Its Evaluation for Full Text Search", IRMA International Conference 2003, (Philadelphia, USA), May (2003)
(13) Y. Yamamoto, S. Ohmi, and H. Tsuji : "Experimental Simulation on Incremental Three-gram Index for Two-gram Full-Text Search System", IEEE/SMC 2003, October (2003)

(14) Y. Yamamoto, S. Ohmi, and H. Tsuji : "Entropy-based Indexing Term Selection For N-gram Text Search System”, IEEE/SMC 2003, October (2003)

(15) Lada A. Adamic, Zipf, Power-laws, and Pareto - a ranking tutorial, http://www.hpl.hp.com/research/idl/papers/ranking/ranking.html （16）J. R. ピアース著：「記号・シグナル・ノイズ」，白揚社（1988）

山本裕 (非会員) 1962 年 9 月 16 日生。 1986 年 3 月

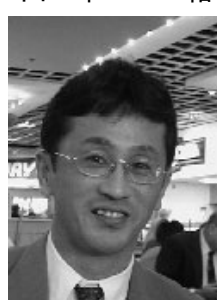
神戸大学卒業。同年（株）日立製作所入社，現 在同社ソフトウェア事業部第 $10 S$ 設計部主任 技師。分散データベースシステム，文書管理シ ステム, 全文・概念検索システムの開発に従事 し，現在メインフレーム系ストレージ管理ソフ トウェアの開発に従事。1995 年〜2001 年 ISO/IEC JTC1/SC32/WG5 委員,情報処理学会 会員。

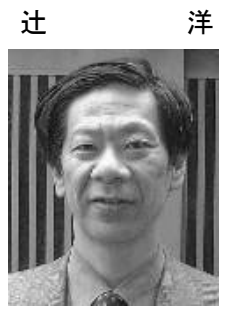

洋 （正員） 1953 年生。1976 年京都大学工学部 数理工学科卒業。1978 年同工学研究科数理工学 専攻修士課程修了。同年，(株)日立製作所入社。 1987 年 1988 年, 米国 Carnegie-Mellon University 客員研究員。2002 年より大阪府立 大学大学院工学研究科経営工学分野教授。博士 (工学), 技術士 (情報工学)。現在, 経営情報シ ステム, 電子商取引, 知識管理, 意思決定支援 システムなどの研究に従事。IEEE, ACM, 情報処理学会, システム 制御情報学会などの会員。 